\title{
Inventarisasi Spesies Mangrove Di Teluk Kertasari, Sumbawa Barat
}

\author{
Inventarization of Mangrove Species in Kertasari Bay, Western Sumbawa
}

\author{
Ahmad Jupri \\ Program Studi Biologi Universitas Mataram \\ Jl. Majapahit No.62 Mataram - Lombok 83125, Telp. (0370)648976E-mail: ajupri_2000@yahoo.com
}

Hutan mangrove atau bakau merupakan salah satu bentuk komunitas yang ada di daerah pasang surut dan khas yang mendukung kehidupan biota lain. Hock and Sasekumar (1979) melaporkan adanya primata yang hidup di hutan mangrove. Primata tersebut adalah monyet ekor panjang (Macaca fascicularis) dan lutung (Presbytis cristata). Selain itu, jenis-jenis burung, kepiting (Aratus pisonii, Erickson et al., 2004), semut (Oecophylla smaragdina, Offenberg et al., 2004). Selain itu, hutan mangrove ini sangat penting sebagai tempat berbiaknya jenis-jenis invertebrate dan ikan.

Selain memiliki nilai bioekologi, hutan mangrove ini juga memiliki nilai ekonomis yang sangat tinggi bagi manusia. Hutan mangrove ini menyediakan berbagai sumber daya alam seperti kayu, jenis-jenis ikan, krustasea, terumbu karang yang dapat menyokong kehidupan masyarakat di sekitarnya. Hutan mangrove ini juga merupakan pelindung bagi wilayah yang ada di belakangnya dari ancaman gelombang air laut (Irawan, 2005; Rahawarin, 2005).

Nusa Tenggara Barat (NTB) yang terdiri dari 2 pulau utama (Lombok dan Sumbawa) memiliki hutan mangrove seluas 4.300 ha. Data keragaman jenis dan karakteristik bioekologi hutan mangrove di NTB sangat kurang. Akibatnya pengelolaan dan pemanfaatan hutan ini tidak maksimal, bahkan cenderung mengalami kerusakan.

Penelitian ini merupakan penelitian awal karena belum ada data dan penelitian sebelumnya. Penelitian ini dilaksanakan di Teluk Kertasari, Desa Kertasari, Kecamatan Taliwang, Kabupaten Sumbawa Barat. Pada saat inventarisasi, kawasan hutan mangrove ini memiliki kondisi yang cukup baik. Pada saat dilakukan penelitian ini, belum ada bekas penebangan atau kerusakan pada vegetas mangrove di tempat ini. Masyarakat di sekita teluk kertasari percaya bahwa hutan mangrov ini adalah penyelamat bagi kehidupan mereka Pengambilan data dilaksanakan bulan Juli Desember 2003. Pengumpulan data dilakuka menggunakan metode point-quarter samplin. (Cox, 2002) dengan 3 transek utama. Dari hasi inventarisasi mangrove di Teluk Kertasari in didapatkan 7 spesies. Spesies tersebut adala Soneratia alba, Rhizophora stylosa Rhizophora sp., Rhizopora apiculata Avicennia marina, Aegiceras corniculatum Ceriops sp.

Sonneratia alba (pedada) merupaka jenis yang umum dijumpai di Teluk Kertasari Spesies ini memiliki nilai penting tertinggi. Ha ini memperlihatkan bahwa spesies ini terseba merata di Teluk Kertasari. Tingginya nila penting yang dimiliki oleh spesies ini karen kemampuan adaptasi spesies ini pad lingkungannya. Dengan kondisi lingkunga Teluk Kertasari yang beragam mulai dar berlumpur tergenang, berpasir basah sampa berbatu sangat mendukung pertumbuha spesies ini. Spesies ini memiliki kemampua fisiologis untuk beradaptasi dengan kondis salinitas yang tinggi dan tanah yang gembu dan anoksik (anaerob). Selain itu, spesies in memiliki kemampuan reproduktif (propagul yang cukup baik.

Selain Sonneratia alba, spesies lain yan, cukup signifikan keberadaannya di Telu. Kertasari adalah Rhizophora stylosa Rhizophora apiculata, dan Avicennia marina Rhizopora stylosa tersebar merata di seluru traksek di Kertasari. Seperti halnya genu Sonneratia, genus Rhizophora juga memilik penyebaran yang cukup luas. Genus ini dapa tumbuh dengan baik pada habitat yan berlumpur (Noor et al., 1999). Genus in 
bersama dengan genus Sonneratia dan Avicennia sering berasosiasi membentuk struktur mangrove terbuka dan mangrove tengah. Struktur mangrove terbuka inilah yang sangat penting sebagai pelindung daerah di belakangnya dari hempasan ombak.

Vegetasi mangrove di Teluk Kertasari sangat penting sebagai habitat bagi beragam jenis biota. Beberapa jenis biota yang tercatat dalam penelitian ini adalah raja udang (Todirhamplus sanctus), punai gagak (Treron sphenura), monyet ekor panjang (Macaca fascicularis), biawak (Varanus sp.) Beragam jenis ikan juga hidup dan berbiak di hutan mangrove Teluk Kertasari. Hal lain yang sangat penting adalah terdapatnya kerang (bivalvia: mollusca) bermata tujuh. Selain itu, di tempat ini juga terdapat karang hijau.

Munjiati (2005) melaporkan terjadinya perubahan komposisi vegetasi mangrove di Teluk Kertasari. Dominansi Sonneratia alba yang pada penelitian tahun 2003 digantikan oleh Aegiceras corniculatum. Hal ini terjadi karena adanya penebangan liar yang terjadi selama kurun waktu 2 tahun. Akibatnya, banyak tegakan mangrove dari kelompok mangrove sejati dengan tinggi lebih dari 3 meter hilang. Saat ini vegetasi mangrove di Teluk Kertasari didominasi oleh mangrove tambahan (associated mangrove). Mengingat pentingnya vegetasi mangrove ini seperti sebagai sumber bahan obat (Purnobasuki, 2004), perlu usaha untuk melestarikannya. Penebangan liar merupakan ancaman serius bagi mangrove di Kertasari. Perlu kesadaran dari berbagi pihak untuk melestarikannya.

\section{Daftar Pustaka}

Cox, G.W. 2002. General Ecology: Laboratory Manua $8^{\text {th }}$ Edition. Mc Graw Hill, London.

Erickson, A.A., Bell, S.S. dan Dawes, C.J. 2004 Doe mangrove leaf chemistry help explain cra herbivory pattern? Biotropica 36 (3): 333 343.

Hock, L.B. dan Sasekumar, A.A. 1979. A Preliminar study on the feeding ecology of mangrov primates, Kuala selangor, The Malay Natural Journal 33 (2): 105-112.

Irawan, B. 2005. Kondisi vegetasi mangrove di wilaya pesisir Kota Banda Aceh dan Aceh Besa Provinsi Nangroe Aceh Darussalam (NAD pasca tsunami. Biotika (4) 1: 50-54

Munjiati, N. 2005. Inventarisai Jenis-Jenis Mangrove c Enam Lokasi Wilayah Pantai dan Pesis Kabupaten Sumbawa Barat. Laporan Prakte Kerja Lapangan Mahasiwa. Program Stuc Biologi Universitas Mataram.

Noor, Y.S., Khazali, M., Suryadiputra, I.N.N. 199 Panduan Pengenalan Mangrove di Indonesic Wetland- Indonesia Programme, Bogor.

Offenberg, J., Aksornkoae, S., MacIntosh, D.J. dar Nielsen, M.G. 2004. Observation on th ecology of weaver ants (Oecophyll smaragdina Fabricius) in Thai Mangrov Ecosystem and their Effect on herbivory Rhizophora mucronata Lam. Biotropica 3 (3): 344-351.

Purnobasuki, H. 2004. Potensi mangrove sebagai tanama obat. Biota 9 (2): 125-126.

Rahawarin, Y.Y. 2005. Komposisi vegetasi mangrove c Muara Sungai Siganoi Sorong Selatan-Papua Biota 10 (3): 134-140.

Tabel 1. Nilai penting setiap spesies mangrove pada transek 1

\begin{tabular}{llccccccc}
\hline \multicolumn{1}{c}{ Spesies } & \multicolumn{1}{c}{ Famili } & KR $(\%)$ & K & D & DR (\%) & F & FR (\%) & NP \\
\hline \hline Sonneratia alba & Sonneratiaceae & 62.5 & 937.5 & 1013.8 & 78.2 & 1,00 & 47.7 & 188.4 \\
Rhizophora stylosa & Rhizoporaceae & 29.1 & 437.5 & 257.5 & 19.9 & 0.7 & 33.3 & 82.3 \\
Avicennia marina & Avicenniaceae & 4.2 & 62.6 & 12.5 & 0.96 & 0.2 & 9.5 & 14.7 \\
Aegiceras corniculatum & Myrsinaceae & 4.2 & 62.6 & 12.5 & 0.96 & 0.2 & 9.5 & 14.7 \\
\hline \hline
\end{tabular}

$\mathrm{KR}=$ kerapatan relative, $\mathrm{K}=$ kerapatan, $\mathrm{D}=$ dominansi, $\mathrm{DR}=$ dominansi relatif, $\mathrm{F}=$ Frekuensi,

$\mathrm{FR}=$ frekuensi relatif, $\mathrm{NP}=$ nilai penting 
Inventarisasi Spesies Mangrove

Tabel 2. Nilai penting setiap spesies mangrove pada transek 2

\begin{tabular}{lllllllll}
\hline \hline \multicolumn{1}{c}{ Spesies } & \multicolumn{1}{c}{ Famili } & KR $(\%)$ & K & D & DR $(\%)$ & F & FR (\%) & NP \\
\hline \hline Sonneratia alba & Sonneratiaceae & 41.7 & 458.7 & 321.1 & 36.0 & 0.5 & 26.3 & 104 \\
Rhizophora stylosa & Rhizoporaceae & 12.5 & 137.5 & 68.8 & 8.0 & 0.3 & 15.8 & 36.3 \\
Xylocarpus granatum & Meliaceae & 4.2 & 46.2 & 46.2 & 5.0 & 0.2 & 10.5 & 19.7 \\
Rhizophora sp & Rhizoporaceae & 4.2 & 46.2 & 27.7 & 3.0 & 0.2 & 10.5 & 17.7 \\
Avicennia marina & Avicenniaceae & 33.3 & 366.3 & 402.9 & 45.0 & 0.5 & 26.3 & 104.6 \\
Ceriops sp. & Rhizoporaceae & 4.2 & 46.2 & 23.1 & 3.0 & 0.2 & 10.5 & 17.7 \\
\hline \hline
\end{tabular}

$\overline{\mathrm{KR}}=$ kerapatan relative, $\mathrm{K}=$ kerapatan, $\mathrm{D}=$ dominansi, $\mathrm{DR}=$ dominansi relatif, $\mathrm{F}=$ Frekuensi,

$\mathrm{FR}=$ frekuensi relatif, $\mathrm{NP}=$ nilai penting

Tabel 3. Nilai penting setiap spesies mangrove pada transek 3

\begin{tabular}{lllllllll}
\hline \hline \multicolumn{1}{c}{ Spesies } & \multicolumn{1}{c}{ Famili } & KR $(\boldsymbol{\%})$ & K & D & DR $(\%)$ & F & FR $(\boldsymbol{\%})$ & NP \\
\hline \hline Sonneratia alba & Sonneratiaceae & 58.3 & 641.1 & 403.9 & 72.7 & 0.8 & 50.0 & 181 \\
Rhizophora apiculata & Rhizoporaceae & 29.2 & 321.2 & 96.36 & 17.4 & 0.5 & 31.2 & 77.8 \\
Rhizophora stylosa & Rhizoporaceae & 12.5 & 137.7 & 55 & 9.9 & 0.3 & 18.8 & 41.2 \\
\hline \hline
\end{tabular}

$\mathrm{KR}=$ kerapatan relative, $\mathrm{K}=$ kerapatan, $\mathrm{D}=$ dominansi, $\mathrm{DR}=$ dominansi relatif, $\mathrm{F}=$ Frekuensi,

$\mathrm{FR}=$ frekuensi relatif, $\mathrm{NP}=$ nilai penting 